\title{
The exotic jumping snail Ovachlamys fulgens (Gude, 1900) (Gastropoda: Helicarionidae) in urban areas of the Upper-Paraná Atlantic Forest
}

\author{
ARIEL A. BELTRAMINO ${ }^{1,2}$, ROBERTO E. VOGLER ${ }^{2,3}$, ALEJANDRA RUMI $^{2,4}$, \\ LEILA B. GUZMÁN ${ }^{1}$, STELLA M. MARTÍ́N $\mathrm{N}^{4,5}$ and JUANA G. PESO ${ }^{3}$ \\ ${ }^{1}$ Departamento de Biología, Facultad de Ciencias Exactas, Químicas y Naturales, Universidad \\ Nacional de Misiones, Rivadavia 2370, N3300LDX Posadas, Misiones, Argentina \\ ${ }^{2}$ Consejo Nacional de Investigaciones Científicas y Técnicas/CONICET, Godoy Cruz 2290, C1425FQB CABA, Argentina \\ ${ }^{3}$ Instituto de Biología Subtropical, Universidad Nacional de Misiones/CONICET, \\ Rivadavia 2370, N3300LDX Posadas, Misiones, Argentina \\ ${ }^{4}$ División Zoología Invertebrados, Facultad de Ciencias Naturales y Museo, Universidad Nacional \\ de La Plata, Paseo del Bosque, s/n, B1900FWA La Plata, Buenos Aires, Argentina \\ ${ }^{5}$ Comisión de Investigaciones Científicas de la Provincia de Buenos Aires/CIC, \\ Calle 526 entre 10 y 11, 1900, La Plata, Buenos Aires, Argentina
}

Manuscript received on September 29, 2017; accepted for publication on December 13, 2017

\begin{abstract}
The exotic land gastropod Ovachlamys fulgens (Gude, 1900), aka the jumping snail, was registered in Eldorado city, Misiones province, constituting the first documented record of that species in Argentinaand for all of South America as well. Identities of the individuals were confirmed through morphological examination, and by a DNA sequencing of the cytochrome oxidase subunit I gene. DNA sequences for the mitochondrial 16S-rRNA and the nuclear 18S-rRNA genes were also obtained from the morphologicallyconfirmed specimens to gain insights into the genetic background of this species in Argentina, and as additional markers for enhancing the rapidity of identification by governmental authorities who are responsible for managing the presence of exotic species. Different size classes suggested that the species had successfully reproduced and become established in the locality. Ovachlamys fulgens is emphasized in the literature as being a serious pest to orchids. Misiones province harbors a high species richness of orchids, representing about one half of the known species in Argentina. Owing to the use of the orchid as an ornamental plant, the commercial trade could have facilitated the introduction of the species into Argentina. Control measures, preventive education, and surveillance are needed to prevent the further spread of this snail.
\end{abstract}

Key words: Argentina, introduced species, Misiones province, molecular markers, nonnative snail.

\section{INTRODUCTION}

In recent decades, South America has been repeatedly affected by several invasive mollusk

Correspondence to: Ariel Anibal Beltramino

E-mail: beltraminoariel@hotmail.com species, as the result of either inadvertent introductions or deliberate installations related to diverse interests, including biological control and ornamental, medicinal, and economic purposes (Cowie and Robinson 2003, Letelier et al. 2007, 
Rumi et al. 2010, Gomes et al. 2011, Vogler et al. 2013, Gołdyn et al. 2017).

Ovachlamys fulgens (Gude 1900), referred to as the jumping snail, is a small helicarionid gastropod of about 5-7 $\mathrm{mm}$ in diameter with the ability to jump when disturbed by using a caudal horn in the posterior region of the foot as a catapult (Barrientos 1998, 2000). This snail, native to the islands of Japan (Gude 1900, Barrientos 2000), is now globally distributed among very distant countries-it being now established in American Samoa (Vargo 2000, Cowie 2001, Cowie et al. 2002), the continental USA (Stange 2004, Robinson and Slapcinsky 2005), Costa Rica (Barrientos 1998, 2000), French Polynesia (Lovenburg 2009), Hawaii (Cowie et al. 2008), Nicaragua (Pérez et al. 2005, Vega et al. 2016), Trinidad and Tobago (Rutherford and Mohammed 2013), as well as in several Southeast-Asian countries like Taiwan, Thailand, and Singapore (Robinson 1999, Robinson and Slapcinsky 2005, Capinera and White 2011, Tsai 2006). Shipments of ornamental plants and horticultural trade have been indicated as the main pathways for the propagation of this exotic species (Robinson 1999, Robinson and Slapcinsky 2005).

Ovachlamys fulgens has a lifespan of about 9 months and can reproduce through self-insemination with no loss of fecundity (Barrientos 1998). Egg deposition starts at around 42 days after hatching, with the eggs being deposited almost daily in small masses of about three eggs each and taking 10-14 days to hatch (Barrientos 1998, Capinera and White 2011). Oviposition occurs in dark damp places up to $1 \mathrm{~cm}$ deep or less (e.g., soil crevices) or in rotten trunks and the leaf litter closest to the soil, which surroundings protect the eggs from desiccation and abrupt changes in temperature (Barrientos 1998, 2000). The eggs are small, averaging $1.84 \mathrm{~mm}$ in diameter, and are laid only semi-hydrated, as they become fully hydrated by absorbing moisture from the substrate (Barrientos 1998, 2000).
Ovachlamys fulgens inhabits areas with considerable moisture and is commonly found among soil litter and on the leaves of plants up to $70 \mathrm{~cm}$ tall (Barrientos 2000). In Costa Rica, the distribution of $O$. fulgens has been correlated with agricultural plantations and areas having secondary growth, as well as with forest remnants close to plantations (Barrientos 2000, 2011). Although this snail can reach comparatively moderate densities with an average up to about 43 living specimens per $\mathrm{m}^{2}$ (Barrientos 2000), the species is currently considered an agricultural and horticultural pest, known to feed on several plant species such as avocados, mangoes, orchids, Heliconia spp., and Dracaena marginata (Robinson 1999, Barrientos 2000, Capinera and White 2011).

In the study reported here, the presence of the jumping snail $O$. fulgens in urban areas of the Upper-Paraná Atlantic Forest was documented for the first time, with that finding also constituting the first confirmed record for the species in South America. We assessed the main conchological and anatomical diagnostic characters (i.e., the shell, genitalia, and radula), and examined DNA sequences of the genes encoding the mitochondrial cytochrome oxidase subunit $I$, the $16 S-r R N A$, and the nuclear $18 S-r R N A$ in order to confirm the identity of this exotic species and in so doing gain insights into the genetic background of the jumping snail in Argentina.

\section{MATERIALS AND METHODS}

The material analyzed (21 specimens) came from Eldorado city, Misiones province, Argentina (Gatherers: Beltramino, A.A., Vogler, R.E., Peso, J.G.; col. date: 18-VIII-2017; geographical coordinates: $26^{\circ} 24^{\prime} 16^{\prime \prime} \mathrm{S}, 54^{\circ} 35^{\prime} 39^{\prime \prime} \mathrm{W}$; $202 \mathrm{~m}$ above sea level) (Fig. 1a). Living specimens were captured during the night while they were involved in full activity among the leaflitter, and on the leaves of Tradescantia zebrina (Commelinaceae) that 

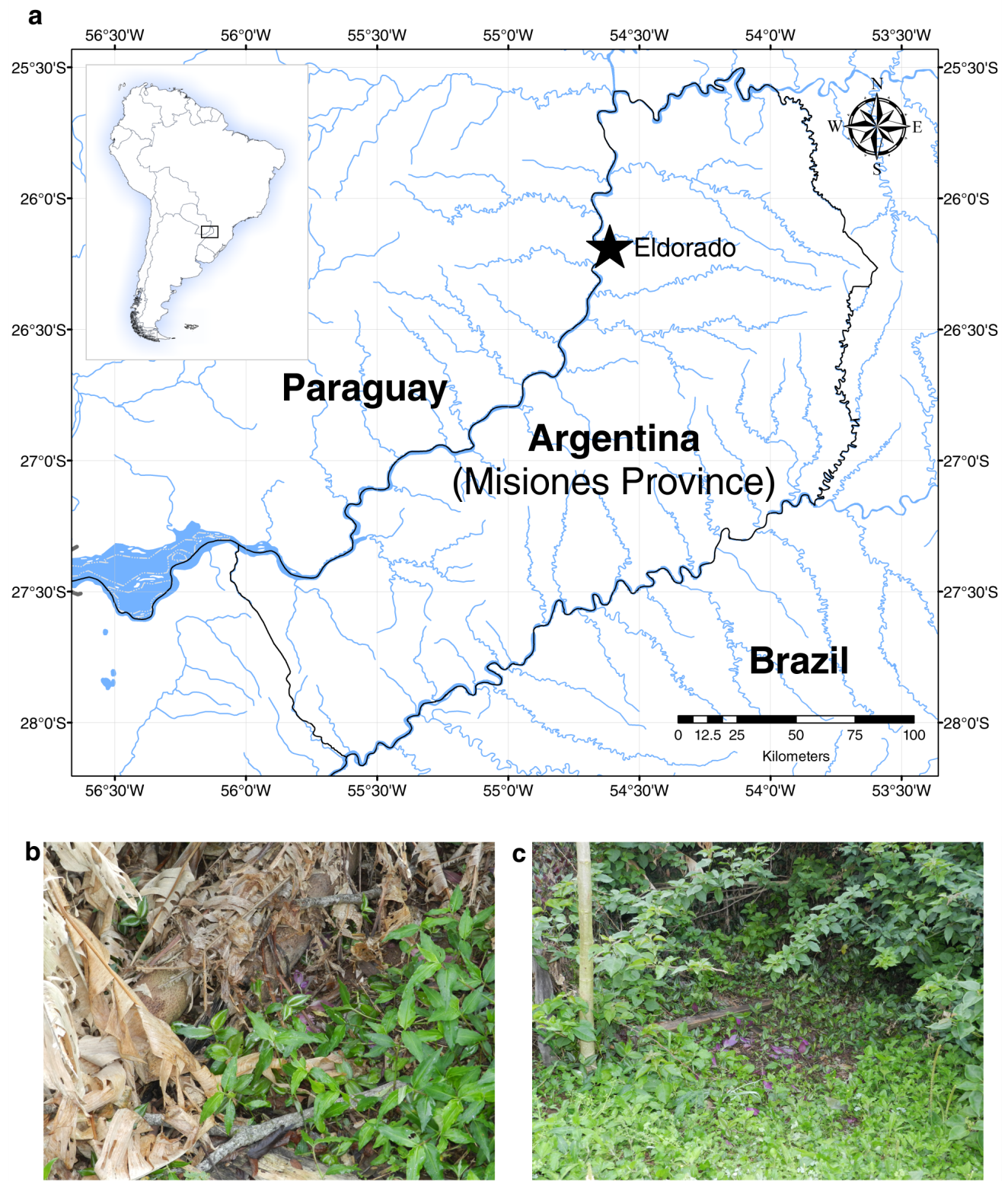

Figure 1 - Map of the Misiones Province in northeastern Argentina and of the sampling environment. a, the black star indicates the locality where Ovachlamys fulgens was recorded; b-c, photographs showing the vegetation types at the sampling site.

were growing underneath the Heliconia rostrata (Heliconiaceae) plants (Fig. 1b, c). The minimum and maximum temperatures during the sampling day were $13{ }^{\circ} \mathrm{C}$ and $26^{\circ} \mathrm{C}$, respectively, while the temperature during actual sampling was $20^{\circ} \mathrm{C}$ and the humidity was $80 \%$. The specimens studied were deposited in the malacological collections at the Instituto de Biología Subtropical, Misiones province (IBS-Ma No. 181, 16 specimens) and the Museo de La Plata (DZI-MLP-Ma), Buenos Aires province (MLP-Ma No. 14476, 5 specimens).

\section{MORPHOLOGICAL STUDIES}

We analyzed the morphology of the shell, jaw, radula, and the reproductive system of $O$. fulgens and took shell measurements on 10 individuals 

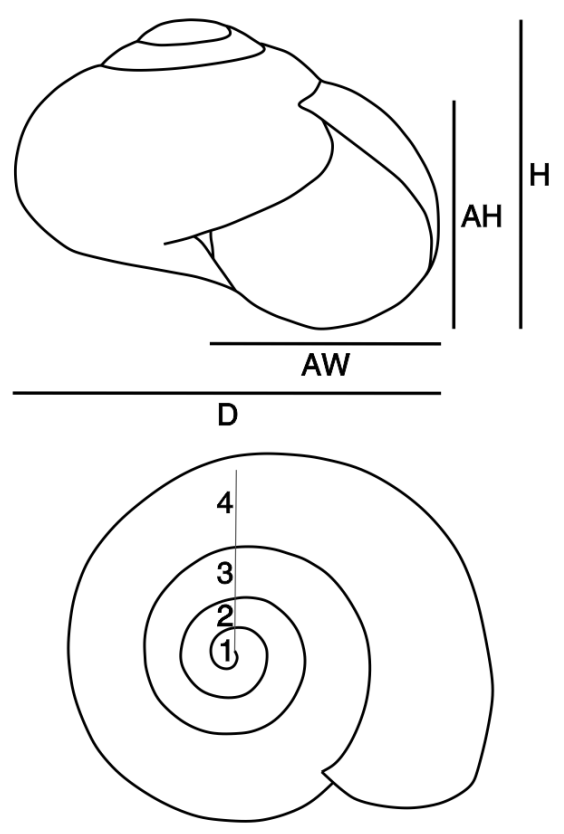

Figure 2 - Shell measurements and whorl count used for Ovachlamys fulgens. Abbreviations: $\mathrm{H}$, height; D, diameter; $\mathrm{AH}$, aperture height; AW, aperture width.

(IBS-Ma Nos. 181/1-181/5, 181/7-181/10, 181/16) following Hyman et al. (2017; Fig. 2)namely, the height $(\mathrm{H}=$ maximum dimension parallel to the axis of coiling), diameter (D $=$ maximum dimension perpendicular to $\mathrm{H}$ ), aperture height $(\mathrm{AH}=$ maximum dimension of the aperture parallel to the axis of coiling), aperture width (AW = maximum dimension of the aperture perpendicular to $\mathrm{H}$ ) and the number of whorls (NW). The shells were measured with a Mitutoyo digital caliper at a precision of $0.01 \mathrm{~mm}$. The specimens were categorized according to three size classes: neonates ( $\mathrm{D} \leq 2.5 \mathrm{~mm}$ ), juveniles ( $\mathrm{D}$ $=2.6-4.9 \mathrm{~mm})$, and adults $(\mathrm{D} \geq 5.0 \mathrm{~mm})$ following Barrientos (2000). The protoconch, the area of the umbilicus, and the radula were also examined with a scanning electron microscope (SEM-JEOL 6360) in the Museum of La Plata. The radula and jaw were separated from the buccal mass of four individuals (IBS-Ma Nos. 181/5, 181/7, 181/9 and 181/16), and cleaned following the enzymatic method detailed by Holznagel (1998). The radular formula is described as in Tanmuangpak et al. (2017). The terminology used for radular description follows Kershaw (1979), Hyman and Ponder (2016), and Tanmuangpak et al. (2017). The genital anatomy was examined through the dissection of five adult specimens (IBS-Ma Nos. 181/11-181/15) preserved in Raillet-Henry solution: $2 \%(\mathrm{v} / \mathrm{v})$ glacial acetic acid, 5\% (v/v) formaldehyde, and 6 $\mathrm{g}$ sodium chloride per liter of distilled water. When necessary, a $0.1 \%(\mathrm{w} / \mathrm{v})$ neutral-red solution was used to enhance the contrast of tissues as described in Vogler et al. (2014). The anatomical features were examined under a Labomed Luxeo 4D stereomicroscope.

DNA EXTRACTION, POLYMERASE CHAIN REACTION (PCR) AMPLIFICATION, AND DNA SEQUENCING

The total DNA was extracted from small samples of foot muscle of five ethanol-preserved specimens (IBS-Ma Nos. 181/1, 181/3, 181/4, 181/6, 181/7) by means of cetyltrimethylammonium bromide (CTAB) protocol. After leaving the ethanol to evaporate, each tissue was digested overnight in $1 \mathrm{ml}$ of CTAB buffer $(2 \%$ [w/v] CTAB, 1.4 $\mathrm{M} \mathrm{NaCl}, 0.2 \%$ [v/v] 2-mercaptoethanol, $20 \mathrm{mM}$ ethylenediaminetetraacetic acid, $100 \mathrm{mM}$ Tris $\mathrm{pH} 7.5)$ containing $5 \mu \mathrm{l}$ proteinase $\mathrm{K}(20 \mathrm{mg} /$ $\mathrm{ml})$. The DNA was then purified by a threefold extraction with chloroform-isoamyl alcohol (24:1) followed by precipitation with cold isopropanol. Partial sequences of the mitochondrial cytochrome oxidase subunit I (COI) and the 16S-rRNA and the nuclear $18 S-r R N A$ genes were amplified through the use of the primers LCO1490 and HCO2198 for COI (Folmer et al. 1994), 16SF-104 and 16SR-472 for the 16S-rRNA locus (Ramírez and Ramírez 2010), and 18SF-566 and 18SR-1200 for the $18 S-r R N A$ sequences (Hadziavdic et al. 2014). The amplifications of the COI gene were conducted following Vogler et al. (2014), and run 
on a T18 thermocycler (Ivema Desarrollos). The amplification of the 16S-rRNA gene was performed as in Rumi et al. (2017) in an OpenPCR thermocycler (Chai Biotechnologies). The amplification of the 18S-rRNA locus was conducted in a total volume of $30 \mu \mathrm{l}$ containing $30-50 \mathrm{ng}$ of template DNA, each primer at $0.5 \mu \mathrm{M}, 1 \mathrm{X}$ green-reaction buffer, $0.2 \mathrm{mM}$ dNTPs, and $1 \mathrm{U}$ GoTaq DNA polymerase (Promega, Madison, WI, USA). The amplification was carried out in a T21 thermocycler (Ivema Desarrollos) as follows: after an initial denaturing for $2 \mathrm{~min}$ at $95^{\circ} \mathrm{C} ; 35$ cycles of $45 \mathrm{~s}$ at $95^{\circ} \mathrm{C}, 1 \mathrm{~min}$ at $60{ }^{\circ} \mathrm{C}, 1 \mathrm{~min}$ at $72{ }^{\circ} \mathrm{C}$ were effected; followed by a final extension at $72{ }^{\circ} \mathrm{C}$ for $7 \mathrm{~min}$. The success of PCR reactions was verified by agarose gel electrophoresis. The PCR products were purified by means of a AccuPrep PCR Purification Kit (Bioneer, Korea). After purification, both DNA strands for each gene were directly cycle-sequenced (Macrogen Inc., Seoul, South Korea). The resulting sequences were trimmed to remove the primers, and the consensus sequences between the forward and reverse sequencings were obtained by means of the BioEdit 7.2.5 software (Hall 1999). The consensus sequences were evaluated for similarities against the GenBank through the use of the BLASTN algorithm (Altschul et al. 1990). Genetic distances were investigated in the MEGA 7.0.26 software (Kumar et al. 2016) through the use of the number of differences $(p)$ and the K2P substitution model.

\section{RESULTS}

\section{MORPHOLOGICAL EXAMINATION}

Shell (Fig. 3). Empty shell thin, helicoidal, glossy, light brown in color, finely sculptured by a series of continuous spiral cords (more than 30) that reached the last whorl; spire conical, depressed; suture shallow; apex obtuse. Specimens exhibited up to 4.5 enveloping whorls, the last whorl being twice the width of the penultimate whorl (Fig. 3a, c; Table I). Columellar margin a little reflected, and nearly covering the very narrow umbilical perforation. Umbilicus with a series of nine nonequidistant spiral cords (Fig. 3d). Protoconch smooth, rounded, with nearly half a whorl (Fig. 3b). The first whorl exhibited a sculpture of equidistant and incomplete transverse ribs from the upper suture (Fig. 3b). Table I lists the shell measurements. The shell morphology of the specimens from Eldorado city was consistent with the original description and drawings by Gude (1900), as well as with color photographs of a syntype of Macrochlamys fulgens (now Ovachlamys fulgens) at the Natural History Museum, London, U.K. (NHMUK 1922.8.29.12, http://data.nhm.ac.uk/dataset/56e711 e6-c8474f99-915a-6894bb5c5dea/resource/05ff2255c38a-40c9-b657-4ccb55ab2feb/record/5555303).

Jaw and Radula (Fig. 4). Jaw membranous, smooth, oxygnath, with extremities rounded and with a distinct median projection (Fig. 4a). Radular teeth arranged in almost straight lines (Fig. 4b) and in up to 85 rows $(n=3)$ with each row containing 95 101 teeth. Radular formula $(42-40)+(8-7)+1+(7-$ $8)+(40-42)$. Central tooth tricuspid, symmetrical with mesocone lanceolate, ectocones small and recessed far back on tooth (Fig. 4c). Lateral and marginal tooth fields distinguishable (Fig. 4b). Lateral teeth, tricuspid; asymmetrical, mesocone elongate; endocone very small, triangular; ectocone robust, triangular, recessed far back on tooth, much larger than central-tooth ectocones (Fig. 4c). Marginal teeth sickle-shaped, tricuspid, mesocone long, endocone less prominent than mesocone; ectocones shorter and narrower than mesocone and endocone, split into extra denticles towards outer edge (Fig. 4d).

Animal (Fig. 5a). Body dark gray; foot sole pale gray, tripartite, central section narrower than lateral sections; caudal horn well developed. Mantle lobes moderately large, not fused.

Genital system (Fig. 5b). The specimens manifested the typology defined for $O$. fulgens, as described by Barrientos (2011). The 


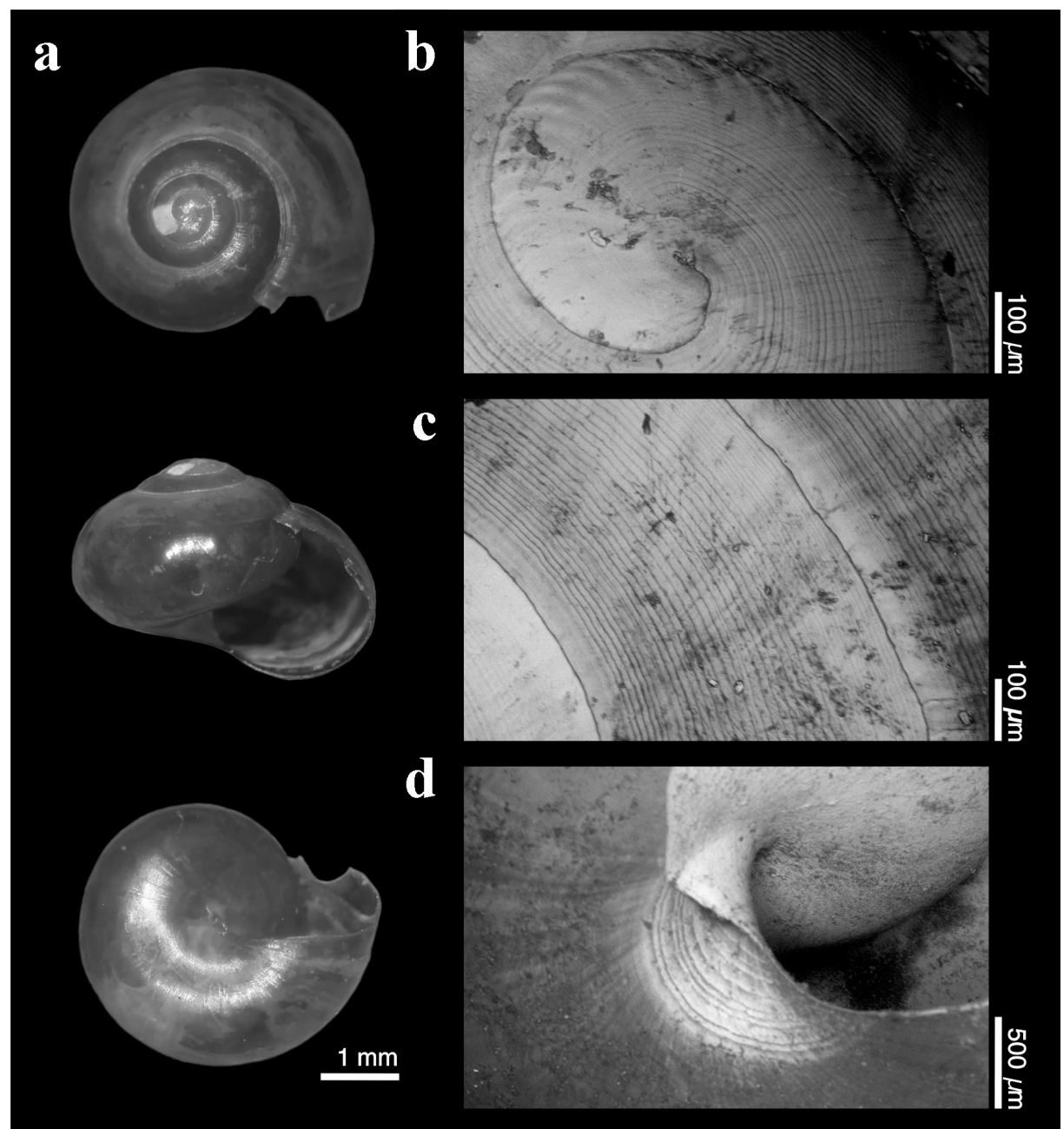

Figure 3 - External-shell morphology of Ovachlamys fulgens from Eldorado city. a, dorsal, apertural, and umbilical views (top to bottom); b-d, scanning electron micrographs: b, protoconch view; c, detail of shell sculpture; $\mathbf{d}$, view of spiral cords at umbilicus.

TABLE I

Shell measurements of Ovachlamys fulgens taken on ten specimens from Eldorado city in the Misiones province of northeastern Argentina.

\begin{tabular}{ccccccc}
\hline Specimen & D & H & AH & AW & NW & Size class \\
\hline IBS-Ma No. 181/1 & 6.39 & 4.43 & 3.55 & 2.93 & 4.4 & Adult \\
IBS-Ma No. 181/2 & 6.39 & 4.18 & 3.49 & 3.57 & 4.5 & Adult \\
IBS-Ma No. 181/3 & 4.95 & 3.35 & 2.63 & 2.66 & 4.3 & Juvenile \\
IBS-Ma No. 181/4 & 5.23 & 3.51 & 2.58 & 2.95 & 4.1 & Adult \\
IBS-Ma No. 181/5 & 5.02 & 3.53 & 2.64 & 2.75 & 4.3 & Adult \\
IBS-Ma No. 181/7 & 4.28 & 2.9 & 2.03 & 2.43 & 3.8 & Juvenile \\
IBS-Ma No. 181/8 & 4.28 & 2.98 & 2.40 & 2.63 & 3.9 & Juvenile \\
IBS-Ma No. 181/9 & 3.41 & 2.40 & 2.09 & 2.14 & 3.8 & Juvenile \\
IBS-Ma No. 181/10 & 3.38 & 1.77 & 1.67 & 1.98 & 3 & Juvenile \\
IBS-Ma No. 181/16 & 2.36 & 1.63 & 1.38 & 1.57 & 2.8 & Neonate \\
\hline
\end{tabular}

Measurements in mm. D, diameter; H, height; AH, aperture height; AW, aperture width; NW, number of whorls. 


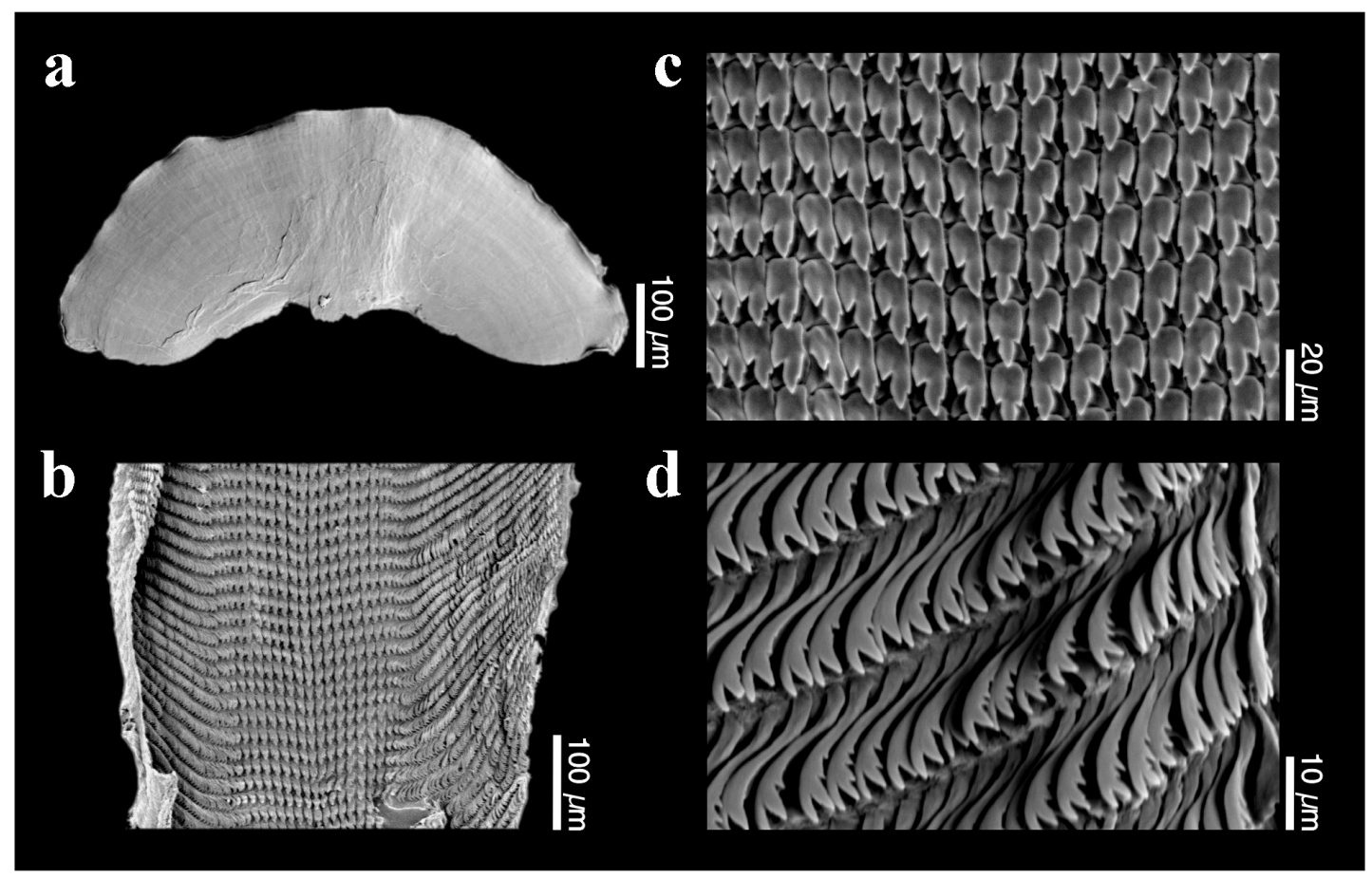

Figure 4 - Scanning electron micrographs of jaw and radula of Ovachlamys fulgens. a, jaw; b, radular segment; c, detail showing central and lateral teeth; $\mathbf{d}$, marginal teeth.
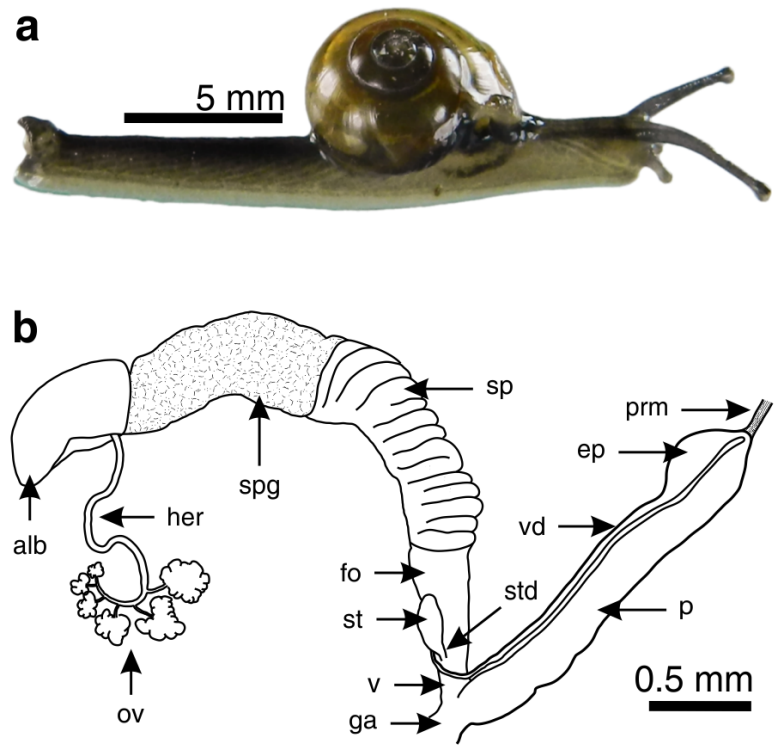

Figure 5 - External morphology and reproductive anatomy of Ovachlamys fulgens. a, living animal; $\mathbf{b}$, schematic drawing of genitalia. Abbreviations: alb, albumen gland; ep, epiphallus; fo, free oviduct; ga, genital atrium; her, hermaphroditic duct; ov, ovotestis; p, penis; prm, penial retractor muscle; sp, spermoviduct; spg, glandular portion of spermoviduct; st, spermatheca; std, spermathecal duct; v, vagina; vd, vas deferens. following distinctive characters are emphasized: spermoviduct elongate, swollen, with numerous tight large folds, and a well-defined glandular area, jelly-like and reaching albumen gland. Vagina simple, cylindrical. Spermatheca globose on female side, short, inserted at junction of free oviduct and vagina, shorter than free oviduct; duct of spermatheca very short. Vas deferens long, thick, roughly the same diameter throughout. Penis long, almost the same diameter throughout. Epiphallus much shorter than penis. Penis-retractor muscle attached to the junction of epiphallus and penis. Penial tunica, epiphallic flagellum, and epiphallic retractor caecum are all absent.

\section{MOLECULAR-GENETIC ANALYSES}

A total of five novel DNA sequences were obtained for each of the three markers analyzed-the latter consisting of 655 bp for COI plus 246 bp for the 16S-rRNA gene and $610 \mathrm{bp}$ for the 18S-rRNA locus. No sequence variation was found within those 
three markers, and a single haplotype per marker was identified. The BLASTN search results, with the COI haplotype obtained from the Eldorado city as the query, exhibited top-ranking scores (query cover $=99 \%$, sequence identity $=100 \%$ ) with the sole sequence available in GenBank from Japan (EF015437, 812 bp), thus confirming the identity of these snails as being Ovachlamys fulgens. When the reference sequence in GenBank was trimmed at both ends to more accurately represent the length of the COI sequences obtained here, the resulting comparisons differed from each other by only two nucleotides, thus representing a sequence divergence among both haplotypes of $0.3 \%$ (genetic distances: $p=0.003, \mathrm{~K} 2 \mathrm{P}=0.003$ ). Owing to the absence of other reference sequences for $O$. fulgens in GenBank, the BLASTN searches identified 18S-rRNA- and 16S-rRNA-encoding sequences as similar to other stylommatophoran and helicarionid gastropods, respectively; thus excluding possible contamination with DNA from other sources. These partial sequences of mitochondrial and nuclear genes from the five specimens from Eldorado have been deposited in GenBank under the single accession number per marker, as follows: COI: MF981089; 16S-rRNA: MF981088; 18S-rRNA: MF981090.

\section{DISCUSSION}

This report documents the presence of the exotic snail $O$. fulgens in urban areas of the Atlantic Forest in northeastern Argentina, which location constitutes one of the global priority ecoregions for the conservation of biodiversity (Di Bitetti et al. 2003). In Argentina, the Upper-Paraná Atlantic Forest, occupying much of the Misiones province, is representative of the Atlantic Forest (Di Bitetti et al. 2003, Gutiérrez Gregoric et al. 2013a). This province contains one of the highest levels of nativemollusk species richness in the country (Rumi et al. 2006, 2008, Núñez et al. 2010, Gutiérrez Gregoric et al. 2013a). To date, 41 exotic-mollusk species have been cited in Argentina (Ferreira et al. 2017); a list that includes over 20 terrestrial gastropod species, of which 11 exotic species have been recorded in the Misiones province (Gutiérrez Gregoric et al. 2013a, b, Virgillito and Miquel 2013).

The morphological studies along with the DNA-sequencing analyses of the COI gene demonstrated that the population surveyed belonged to the jumping snail $O$. fulgens. The different size classes recorded furthermore suggested that the species had been successfully reproduced and was thoroughly established in the new locality. This finding constitutes the first record of the presence of the genus in Argentina and, to the best of our knowledge, is also the first documentation of an established population of the species in all of South America; although the species had been detected on and removed from cut flowers from Colombia shipped to the USA, thus suggesting that the species would also be present in that South American country (Robinson and Slapcinsky 2005). Since surveys of terrestrial gastropods from the Misiones province conducted up to 2010 did not report the presence of $O$. fulgens (Gutiérrez Gregoric et al. 2013a), the likelihood is that the species was introduced within the past 7 years. In addition, no genetic variation and but a single haplotype was identified for each of the three molecular markers examined. At the time of this study, only a single COI sequence for $O$. fulgens from Japan was available in GenBank for comparison (Hyman et al. 2007), which sequence differed by $0.3 \%$ in terms of genetic distance from the one reported here. We expect that the molecular-genetic data generated here will contribute to an assessment of the sequence variation in established populations from around the globe and to a reconstruction of the invasion routes of the species, as has already been performed by Fontanilla et al. (2014) for the giant African snail Achatina fulica Bowdich, 1822 (Achatinidae). 
To date, the pathway for the introduction of $O$. fulgens into Argentina remains unclear, but could be related to human inadvertent transport possibly in association with the commerce of ornamental plants and the horticultural trade, either directly attached to the vegetation or-perhaps more likelyin the accompanying soil (Cowie 2001, Cowie and Robinson 2003, Cowie et al. 2008). Since the jumping snail has evidenced a reproductive strategy that requires no cross-fertilization-and one in which the egg viability has been found to be considerably high (Barrientos 1998)-the species's introduction into Argentina may have occurred through a single reproducing individual from virtually anywhere else. The Misiones province, however, is located in the extreme northeastern corner of Argentina, bordering on Brazil and Paraguay. The introduction pathway for other exotic gastropod species recorded in Misionessuch as A. fulica, and the slug Meghimatium pictum (Stolyczka, 1873) (Philomycidae)-were suggested to be linked to a dispersion from Brazil and/or to the commerce of flora (Gutiérrez Gregoric et al. 2011, $2013 \mathrm{~b}$ ). Thus, in view of the intense commercial trade with the neighboring countries, the presence of $O$. fulgens in Paraguay and southernmost States of Brazil (Paraná, Santa Catarina and Rio Grande do Sul) should not be discounted. Recently, Teixeira et al. (2017) have reported the presence of living specimens of helicarionid snails in São Paulo State, which were tentatively assigned to $O$. fulgens based on shell features and escape behavior. Further taxonomic confirmation of those specimens at the species level by reproductive anatomy and sequencing would imply that $O$. fulgens is widespread across distant regions of the Atlantic Forest; in this scenario, the geographical profile of this species needs to be carefully surveyed.

Ovachlamys fulgens is known to be a pest in agricultural fields in Costa Rica (Barrientos 2000), where the vegetation type in locations in which the species has become established in that country include Araceae, Dracaena marginata, Heliconia spp., Musa paradisiaca, Orchidaceae, Pennisetum purpureum, Poaceae (Bamboo), and Yucca elephantipes among others (Barrientos 2000, Hidalgo Jaminson 2012). Moreover, the species has been intercepted entering the USA on a wide variety of plants such as Anthurium sp., Euonymus japonicus, Heliconia spp., and Dracaena spp. as well as on roses (Cowie 2000, NAPPO 2002, Stange 2004, Weaver 2004, Forestry Images 2017). While many of these plant species are present in Misiones, they are not part of large-scale production systems, and if produced, only so on a small-scale for commercialization within the region. Nevertheless, potential economic losses might occur if large-scale plantations in the Misiones province-such as tea (Camellia sinensis), mate (Ilex paraguariensis), and tobacco (Nicotiana tabacum)-are affected, which commodities represent the $95 \%, 87 \%$, and $25 \%$ of the national production respectively (Izquierdo et al. 2008, Gutiérrez Gregoric et al. 2011, DINREP 2015, MHYFP 2016). Since the dietary preferences of $O$. fulgens on these agricultural species are unknown, a risk analyses need to be undertaken to consider the relevance of these industrial crops to Argentine national production.

Ovachlamys fulgens has been reported to act as an intermediate host of the parasitic nematode Angiostrongylus cantonensis (Chen, 1935), which pathogen is responsible for eosinophilic meningitis, an emerging infectious disease that affects the central nervous system (Kim et al. 2014). This nematode species is widespread in many parts of Brazil including the southern States surrounding the Misiones province (Morassutti et al. 2014). Although the parasite has not yet been reported in Argentina, that nematode's potential presence is being monitored in the country because of the occurrence of A. fulica in Brazil, where that species has been demonstrated as having a high transmission potential and susceptibility to infection by $A$. cantonensis (Morassutti et al. 
2014, Valente et al. 2016, 2017). In addition, in the area where $O$. fulgens was detected, several other gastropod species (both native and exotic), can act as intermediate hosts for the zoonotic parasitic nematode Angiostrongylus costaricensis Moreira and Céspedes, 1971 responsible for abdominal angiostrongyliasis. Since the potential risk that $O$. fulgens could begin to act as a new vector for parasitic nematodes relevant to public health, further epidemiological monitoring and parasitological investigations are required.

Furthermore, Eldorado city is located in a mosaic of native forest, plantations, agriculture, and pastures. Within a radius of less than $100 \mathrm{~km}$, large remaining areas of Upper-Paraná Atlantic Forest still persist and include protected areas such as the Iguazú National Park (54384 ha), Urugua-í Provincial Park (84000 ha), and Puerto Península Provincial Park (6900 ha) (Gutiérrez Gregoric et al. 2011, DeMatteo et al. 2017). As to O. fulgens in Costa Rica, Barrientos (2000) suggested that the snail may become established preferentially in forest remnants close to plantations; likewise, on the basis of observations in American Samoa, Cowie (2000) indicated that $O$. fulgens could become a dominant species in native forests. Although the capability of this snail for penetrating undisturbed native forest still remains unexplored, the potential introduction of the species into these areas of the Upper-Paraná Atlantic Forest may pose a threat to native terrestrial mollusks through competition for food and refuge; and, at the very least, $O$. fulgens is already known to be a pest of orchids (Capinera and White 2011). In Argentina, the orchid family is represented by ca. 280 species; and about 154 of those have been recognized in the Misiones province, with many already being threatened with extinction by either extractive practices or habitat destruction (Dalzotto and Lallana 2013, and references therein). Further studies are required to ascertain if native orchids have already been affected and if $O$. fulgens may be spreading through the orchid trade since orchids are among the most appreciated ornamental plants of greater commercial value (Colombo et al. 2004). Complimentary ecological studies are also needed to understand the impact of this exotic species on terrestrial ecosystems of the Upper-Paraná Atlantic Forest.

Finally, O. fulgens has been considered a harmful invasive species in the USA and has been suggested for a status of national quarantine of the highest order (Cowie et al. 2009, Cournand 2016). In this report, we provide the first documentation of this exotic snail within Argentine territory. Because of the snail's invasive capabilities, by virtue of its polyphagous feeding habits and uniparental reproduction, we believe that the information provided here will help nonspecialists and government authorities alike to make a rapid and facile identification of the species. We expect that the pest control and management authorities can use this information to establish priority areas for surveillance and to plan preventive actions aimed at limiting the spread and impact of the jumping snail in Argentina and elsewhere.

\section{ACKNOWLEDGMENTS}

To Dr. Donald F. Haggerty, a retired academic career investigator and native English speaker, edited the final version of the manuscript. This study was financially supported by Facultad de Ciencias Naturales y Museo, Universidad Nacional de La Plata (Programa Nacional de Incentivos Docentes, N727), and Facultad de Ciencias Exactas, Químicas y Naturales, Universidad Nacional de Misiones (Proyecto de Investigación 16Q634).

\section{REFERENCES}

ALTSCHUL SF, GISH W, MILLER W, MYERS EW AND LIPMAN DJ. 1990. Basic local alignment search tool. J Mol Biol 215: 403-410.

BARRIENTOS Z. 1998. Life history of the terrestrial snail Ovachlamys fulgens (Stylommatophora: Helicarionidae) under laboratory conditions. Rev Biol Trop 46: 369-384. 
BARRIENTOS Z. 2000. Population dynamics and spatial distribution of the terrestrial snail Ovachlamys fulgens (Stylommatopbora: Helicarionidae) in a tropical environment. Rev Biol Trop 48: 71-87.

BARRIENTOS Z. 2011. Ovachlamys fulgens. In: Biodiversidad de Costa Rica. Available at: http://www.crbio.cr:8080/ neoportal-web/species/Ovachlamys\%20fulgens. Accessed on September 3, 2017.

CAPINERA JL AND WHITE J. 2011. Terrestrial snails affecting plants in Florida. Publication number EENY497. Gainesville: Department of Entomology, University of Florida, $12 \mathrm{p}$.

COLOMBO LA, DE FARIA RT, DE CARVALHO JFRP, DE ASSIS AM AND DE BATISTA FONSECA IC. 2004. Influência do fungicida clorotalonil no desenvolvimento vegetativo e no enraizamento de duas espécies de orquídeas brasileiras. Acta Sci Agron 26: 253-258.

COURNAND MJ. 2016. Ovachlamys fulgens (Orchid Snail). In: The Online Guide to the Animals of Trinidad and Tobago. Trinidad: The University of the West Indies, 3 p. Available at: https://sta.uwi.edu/fst/lifesciences/ documents/Ovachlamys_fulgens.pdf. Accessed on September 6, 2017.

COWIE RH. 2000. Non-indigenous land and freshwater molluscs in the islands of the Pacific: conservation impacts and threats. In: Sherley G (Ed), Invasive species in the Pacific: A technical review and draft regional strategy, Apia: South Pacific Regional Environment Programme, p. 143-172.

COWIE RH. 2001. Decline and homogenization of Pacific faunas: the land snails of American Samoa. Biol Conserv 99: 207-222.

COWIE RH, DILLON JR RT, ROBINSON DG AND SMITH JW. 2009. Alien non-marine snails and slugs of priority quarantine importance in the United States: A preliminary risk assessment. Am Malacol Bull 27: 113-132.

COWIE RH, HAYES KA, TRAN CT AND MEYER III WM. 2008. The horticultural industry as a vector of alien snails and slugs: widespread invasions in Hawaii. Int J Pest Manag 54: 267-276.

COWIE RH AND ROBINSON DG. 2003. Pathways of introduction of nonindigenous land and freshwater snails and slugs. In: Ruiz G and Carlton JT (Eds), Invasive species: vectors and management strategies, Washington DC: Island Press, p. 93-122.

COWIE RH, RUNDELL RJ, MIKA F AND SETU P. 2002. The endangered partulid tree snail Samoana thurstoni on Olosega and the land snail diversity of the Manu'a Islands, American Samoa. Am Malacol Bull 17: 37-43.

DALZOTTO CA AND LALLANA VH. 2013. Viabilidad, germinación asimbiótica y vigor de tres especies de orquídeas nativas. Rev Cient Agropecu 17: 39-47.
DEMATTEO KE, RINAS MA, ZURANO JP, SELLESKI N, SCHNEIDER RG AND ARGÜELLES CF. 2017. Using niche-modelling and species-specific cost analyses to determine a multispecies corridor in a fragmented landscape. PLoS ONE 12(8): e0183648.

DI BITETTI MS, PLACCI G AND DIETZ LA. 2003. Una visión de biodiversidad para la ecorregión del Bosque Atlántico del Alto Paraná: diseño de un paisaje para la conservación de la biodiversidad y prioridades para las acciones de conservación. Washington DC: World Wildlife Fund, $154 \mathrm{p}$.

DINREP. 2015. Misiones. In: Informes Sintéticos de Caracterización Socio-Productiva. Buenos Aires: Dirección Nacional de Relaciones Económicas con las Provincias, 21 p. Available at: http://www2.mecon.gov. ar/hacienda/dinrep/Informes/archivos/misiones.pdf. Accessed on September 3, 2017.

FERREIRA AC, PAZ EL, RUMI A, OCON C, ALTIERI P AND RODRIGUES CAPÍTULO A. 2017. Ecology of the non-native snail Sinotaia of quadrata (Caenogastropoda: Viviparidae). A study in a lowland stream of South America with different water qualities. An Acad Bras Cienc 89: 1059-1072.

FOLMER O, BLACK M, HOEH W, LUTZ R AND VRIJENHOEK R. 1994. DNA primers for amplification of mitochondrial cytochrome $c$ oxidase subunit I from diverse metazoan invertebrates. Mol Mar Biol Biotechnol 3: 294-299.

FONTANILLA IKC, MARIA IMPS, GARCIA JRM, GHATE H, NAGGS F AND WADE CM. 2014. Restricted genetic variation in populations of Achatina (Lissachatina) fulica outside of East Africa and the Indian Ocean Islands points to the Indian Ocean Islands as the earliest known common source. PLoS ONE 9: e105151.

FORESTRY IMAGES. 2017. Ovachlamys fulgens (Gude, 1900). Available at: https://www.forestryimages.org/ browse/subimages.cfm?sub=11775\&order $=306$. Accessed on September 3, 2017.

GOŁDYN B, KACZMAREK Ł, ROSZKOWSKA M, GUAYASAMÍN PR, KSIĄŻKIEWICZ-PARULSKA Z AND CERDA H. 2017. Urban ecology of invasive giant African snail Achatina fulica (Férussac) (Gastropoda: Achatinidae) on its first recorded sites in the Ecuadorian Amazon. Am Malacol Bull 35: 59-64.

GOMES SR, PICANÇO JB, COLLEY E, AGUDO-PADRÓN AI, NAKANO E AND THOMÉ JW. 2011. A newly introduced and invasive land slug in Brazil: Meghimatium pictum (Gastropoda, Philomycidae) from China. Proc Acad Nat Sci Philadelphia 161: 87-95.

GUDE GK. 1900. Further notes on helicoid land shells from Japan, the Loo-Choo, and Bonin Islands, with descriptions of seven new species. J Molluscan Stud 4: 70-80. 
GUTIÉRREZ GREGORIC DE, BELTRAMINO AA, VOGLER RE, CUEZZO MG, NÚÑEZ V, GOMES SR, VIRGILLITO M AND MIQUEL SE. 2013b. First records of four exotic slugs in Argentina. Am Malacol Bull 31: 245-256.

GUTIÉRREZ GREGORIC DE, NÚÑEZ V, VOGLER RE, BELTRAMINO AA AND RUMI A. 2013a. Gasterópodos terrestres de la provincia de Misiones, Argentina. Rev Biol Trop 61: 1759-1768.

GUTIÉRREZ GREGORIC DE, NÚÑEZ V, VOGLER RE AND RUMI A. 2011. Invasion of the Argentinean Paranense rainforest by the giant African snail Achatina fulica. Am Malacol Bull 19: 135-137.

HADZIAVDIC K, LEKANG K, LANZEN A, JONASSEN I, THOMPSON EM AND TROEDSSON C. 2014. Characterization of the 18S rRNA gene for designing universal eukaryote specific primers. PLoS ONE 9: e87624.

HALL TA. 1999. BioEdit: a user-friendly biological sequence alignment editor and analysis program for Windows 95/98/ NT. Nucleic Acids Symp Ser 41: 95-98.

HIDALGO JAMINSON E. 2012. Generating knowledge about the Dracaena marginata pest complex to improve management strategies for crops exported from Costa Rica. Costa Rica: Centro Agronómico Tropical de Investigación y Enseñanza, 96 p.

HOLZNAGEL W. 1998. A nondestructive method for cleaning gastropod radulae from frozen, alcohol-fixed, or dried material. Am Malacol Bull 14: 181-183.

HYMAN IT, DE LA IGLESIA LAMBORENA I AND KÖHLER F. 2017. Molecular phylogenetics and systematic revision of the south-eastern Australian Helicarionidae (Gastropoda, Stylommatophora). Contrib Zool 86: 51-95.

HYMAN IT, HO SYW AND JERMIIN LS. 2007. Molecular phylogeny of Australian Helicarionidae, Euconulidae and related groups (Gastropoda: Pulmonata: Stylommatophora) based on mitochondrial DNA. Mol Phylogenet Evol 45: 792-812.

HYMAN IT AND PONDER WF. 2016. Helicarionidae (Gastropoda: Heterobranchia: Stylommatophora) of Lord Howe Island. Molluscan Res 36: 84-107.

IZQUIERDO AE, DE ANGELO CD AND AIDE TM. 2008. Thirty years of human demography and land-use change in the Atlantic Forest of Misiones, Argentina: an evaluation of the forest transition model. Ecol Soc 13, p. 3.

KERSHAW RC. 1979. Redescription of Helicarion cuvieri from Southern Tasmania and Helicarion freycineti from New South Wales (Pulmonata: Helicarionidae). J Malac Soc Aust 4: 145-156.

KIM JR, HAYES KA, YEUNG NW AND COWIE RH. 2014. Diverse gastropod hosts of Angiostrongylus cantonensis, the rat lungworm, globally and with a focus on the Hawaiian Islands. PLoS ONE 9: e94969.
KUMAR S, STECHER G AND TAMURA K. 2016. MEGA7: Molecular evolutionary genetics analysis version 7.0 for bigger datasets. Mol Biol Evol 33: 1870-1874.

LETELIER VS, RAMOS LAM AND HUAQUÍN MLG. 2007. Moluscos dulceacuícolas exóticos en Chile. Rev Mex Biodivers 78: 9S-13S.

LOVENBURG V. 2009. Terrestrial gastropod distributional factors: native and nonnative forests, elevation and predation on Mo'orea, French Polynesia. UCB Moorea Class: Biology and Geomorphology of Tropical Islands. Available at: http://www.escholarship.org/uc/ item/73t4j6xs. Accessed on September 2, 2017.

MHYFP. 2016. Informes de cadena de valor. Yerba Mate. Año 1. No 9. Buenos Aires: Ministerio de Hacienda y Finanzas Públicas de la Nación, 36 p. Available at: https://www. economia.gob.ar/peconomica/docs/SSPE_Cadenas $\% 20$ de\%20valor_Yerba\%20Mate.pdf. Accessed on September 3, 2017.

MORASSUTTI AL, THIENGO SC, FERNANDEZ M, SAWANYAWISUTH K AND GRAEFF-TEIXEIRA C. 2014. Eosinophilic meningitis caused by Angiostrongylus cantonensis: an emergent disease in Brazil. Mem Inst Oswaldo Cruz 109: 399-407.

NAPPO. 2002. A new snail detected on cut roses from Colombia. In: North American Plant Protection Organization's (NAPPO) Phytosanitary Alert System. Available at: http://www.pestalert.org/viewArchNewsStory. c fm? nid $=218 \&$ keyword=ovachlamys $\% 20$ fulgens. Accessed on September 3, 2017.

NÚÑEZ V, GUTIÉRREZ GREGORIC DE AND RUMI A. 2010. Freshwater gastropod provinces from Argentina. Malacologia 53: 47-60.

PÉREZ AM, BORNEMANN G, CAMPO L, SOTELO M, RAMÍREZ F AND ARANA I. 2005. Relaciones entre biodiversidad y producción en sistemas silvopastoriles de América Central. Ecosistemas 14: 132-141.

RAMÍREZ J AND RAMÍREZ R. 2010. Analysis of the secondary structure of mitochondrial LSU rRNA of Peruvian land snails (Orthalicidae: Gastropoda). Rev Per Biol 17: 53-57.

ROBINSON DG. 1999. Alien invasions: the effects of the global economy on nonmarine gastropod introductions into the United States. Malacologia 41: 413-438.

ROBINSON DG AND SLAPCINSKY J. 2005. Recent introductions of alien land snails into North America. Am Malacol Bull 20: 89-93.

RUMI A, GUTIÉRREZ GREGORIC DE, NÚÑEZ V, CÉSAR II, ROCHE MA, TASSARA MP, MARTÍN SM AND LÓPEZ ARMENGOL F. 2006. Freshwater Gastropoda from Argentina: species richness, distribution patterns, and an evaluation of endangered species. Malacologia 49: 189-208. 
RUMI A, GUTIÉRREZ GREGORIC DE, NÚÑEZ V AND DARRIGRAN GA. 2008. Malacología Latinoamericana. Moluscos de agua dulce de Argentina. Rev Biol Trop 56: 77-111.

RUMI A, SÁNCHEZ J AND FERRANDO NS. 2010. Theba pisana (Müller, 1774) (Gastropoda, Helicidae) and other alien land molluscs species in Argentina. Biol Invasions 12: 2985-2990.

RUMI A, VOGLER RE AND BELTRAMINO AA. 2017. The South-American distribution and southernmost record of Biomphalaria peregrina - a potential intermediate host of schistosomiasis. PeerJ 5: e3401.

RUTHERFORD MG AND MOHAMMED R. 2013. New and updated records of terrestrial and freshwater gastropod molluscs for Tobago, West Indies. Living World. J Trinidad and Tobago Field Naturalists' Club 2013: 71-72.

STANGE LA. 2004. Pest alert. Snails and Slugs of Regulatory Significance to Florida. Florida Department of Agriculture and Consumer Services, Division of Plant Industry. Available at: http:/www.freshfromflorida.com/content/ download/68158/1612653/Pest_Alert_-_SNails_and_ Slugs_GALS.pdf. Accessed on September 2, 2017.

TANMUANGPAK K, TUMPEESUWANA C AND TUMPEESUWANA S. 2017. A new species of Sesara Albers, 1860 from northeastern Thailand (Stylommatophora: Helicarionidae). Molluscan Res 37: $1-7$.

TEIXEIRA L, CUNHA CM AND BORNSCHEIN MR. 2017. First record of the Japanese land snail Ovachlamys fulgens (Gude, 1900) (Gastropoda, Helicarionidae) in Brazil. Check List 13: 703-706.
TSAI CL. 2006. 防疫檢疫上所遭遇之軟體類動物（二） 一蝸牛類之簡介. 植物重要防疫檢疫害蟲診斷鑑定研 習會 6: 135-144. [In Chinese].

VALENTE R, DIAZ JI, LORENTI E, SALOMÓN OD AND NAVONE GT. 2016. Nematodes from Achatina fulica Bowdich, 1822 (Mollusca: Gastropoda) in Argentina. Helminthol 53: 109-112.

VALENTE R, DIAZ JI, SALOMÓN OD AND NAVONE GT. 2017. Natural infection of the feline lungworm Aelurostrongylus abstrusus in the invasive snail Achatina fulica from Argentina. Vet Parasitol 235: 17-19.

VARGO DL. 2000. Soil invertebrates of American Samoa. Micronesica 33: 1-10.

VEGA GH, LÓPEZ SJA, URCUYO J AND MEDINA FITORIA A. 2016. Moluscos continentales del Río Grande de Matagalpa, RACCS, Nicaragua (Sección Tumarín, área proyectada del embalse). Rev Nicar Biodivers 9: 3-19.

VIRGILLITO M AND MIQUEL SE. 2013. New records of exotic land snails and slugs in Argentina. Rev Mus Argentino Cienc Nat 152: 295-303.

VOGLER RE, BELTRAMINO AA, PESO JG AND RUMI A. 2014. Threatened gastropods under the evolutionary genetic species concept: redescription and new species of the genus Aylacostoma (Gastropoda: Thiaridae) from High Paraná River (Argentina-Paraguay). Zool J Linn Soc 172: 501-520.

VOGLER RE, BELTRAMINO AA, SEDE MM, GUTIÉRREZ GREGORIC DE, NÚÑEZ V AND RUMI A. 2013. The giant African snail, Achatina fulica (Gastropoda: Achatinidae): using bioclimatic models to identify South American areas susceptible to invasion. Am Malacol Bull 31: 39-50.

WEAVER RE. 2004. Botany Section. Tri-ology 43(3): 1-14. 